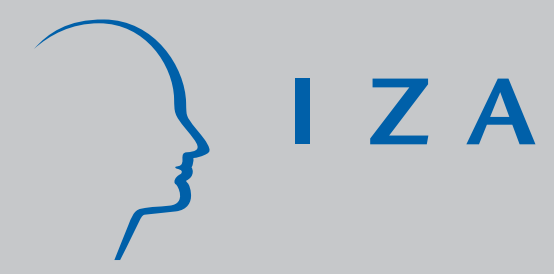

IZADP No. 1575

Pathways to Early Retirement in Denmark, 1984-2000

Mona Larsen

Peder J . Pedersen

April 2005 


\title{
Pathways to Early Retirement in Denmark, 1984-2000
}

\author{
Mona Larsen \\ Danish National Institute of Social Research, Aarhus School of Business \\ and Graduate School for Integration, Production and Welfare \\ Peder J. Pedersen \\ University of Aarhus, Danish National Institute of Social Research \\ and IZA Bonn
}
Discussion Paper No. 1575
April 2005

\author{
IZA \\ P.O. Box 7240 \\ 53072 Bonn \\ Germany \\ Phone: +49-228-3894-0 \\ Fax: +49-228-3894-180 \\ Email: iza@iza.org
}

Any opinions expressed here are those of the author(s) and not those of the institute. Research disseminated by IZA may include views on policy, but the institute itself takes no institutional policy positions.

The Institute for the Study of Labor (IZA) in Bonn is a local and virtual international research center and a place of communication between science, politics and business. IZA is an independent nonprofit company supported by Deutsche Post World Net. The center is associated with the University of Bonn and offers a stimulating research environment through its research networks, research support, and visitors and doctoral programs. IZA engages in (i) original and internationally competitive research in all fields of labor economics, (ii) development of policy concepts, and (iii) dissemination of research results and concepts to the interested public.

IZA Discussion Papers often represent preliminary work and are circulated to encourage discussion. Citation of such a paper should account for its provisional character. A revised version may be available directly from the author. 


\section{ABSTRACT \\ Pathways to Early Retirement in Denmark, 1984-2000*}

This paper describes and analyses the pathways to early retirement in Denmark. The analyses are based on a 10 per cent panel sample of the population 45-66 years old followed from 1984 onwards. We use a multinomial logit approach to analyse the characteristics of individuals that retire through each pathway compared to those remaining in the labour force. The transition from work to retirement is complex and far from the conventional idea of exit typically occurring from a job at the official pension age. Eight pathways from work to an early retirement program are identified. One group of pathways is transitions directly from employment corresponding to 75 per cent of all transitions in the sample period. The great majority of these transitions occur to an early retirement program. A second group consists of pathways dominated by unemployment insurance benefits (UIB) covering 20 per cent. The remaining 5 per cent of the transitions occur through pathways dominated by benefit programs reflecting a low attachment to the labour force in the period prior to retirement. Overall, availability and/or generosity of retirement programs are important for early retirement through the employment and UIB dominated pathways. For early retirement through other pathways, however, personal characteristics seem to be at least as important as retirement programs.

JEL Classification: J14, J26

Keywords: retirement, pathways, panel data

Corresponding author:

Peder J. Pedersen

Department of Economics

Aarhus University

Bygning 322

8000 Århus C

Denmark

Email: ppedersen@econ.au.dk

\footnotetext{
* This work is part of the research of the Graduate School for Integration, Production and Welfare. Financial support from the Danish Social Science Research Council is gratefully acknowledged. We are grateful for comments from Michael Rosholm, Peter Jensen and other participants at a Seminar on Welfare Research in December 2003 in Nyborg, from a referee and participants at the conference on Transitions and Risk, University of Melbourne, February 2005, and from participants at a seminar at the Danish National Institute of Social Research, March 2005.
} 


\section{Introduction}

Traditionally, work and retirement has been considered as distinct states, reflecting the idea of a life cycle where full-time employment in a job is followed directly at a specific and common age by exit from the labour force at the official retirement age. However, OECD (2003) presents evidence for the member countries showing that withdrawal from the labour market starts well before the official retirement age. The range of labour market participation rates across the countries is very big for the age group 50 to 64 years old in 2000, i.e. with a range between 40.2 per cent in Belgium and 89.9 per cent in Iceland. The period between full-time work and retirement at the official pension age can be bridged by part-time work. However, the great majority of people do not reduce their labour supply gradually in this way but instead enter an early retirement program. This could be either programs financed mainly from public sector budgets or it could be take up of labour market pensions or private pensions programs at an actuarial discount before the official retirement age.

The focus in the present paper is on the spell of time between leaving the last job and entry into a retirement program and the question we analyse in the paper is how people allocate into a number of pathways between the last job and entry to a retirement program. Kohli and Rein (1991) define a pathway as an institutional arrangement or a sequential combination of a number of arrangements making a bridge between the exit from work and entry into the normal Old age pension (OAP). In the present paper we use a broader concept and focus on pathways leading to exit from the labour force into a number of programs for early retirement. The dominant approach in retirement studies is on destinations, i.e. which program people enter conditional on retirement. In the present paper the analytical focus is instead on how people span the period from leaving the job until entry to a retirement program. In many OECD countries reforms of retirement programs are on the policy agenda making it useful to know how people arrive to the different retirement destinations. Using a comprehensive panel data set we go back in time from a specific year in the sample period and determine when people in early retirement left their most recent job and how they were provided for until retirement. During the transition from work to early retirement people can derive an income from unemployment insurance benefits, sickness benefits or social welfare benefits or from sequential combinations of such benefits. 
We identify eight different pathways to early retirement. The pathways differ between some, which are choice based and others for which people are only eligible after having passed a visitation based on medical and/or social criteria. An optimisation model for the selection of pathways from work is thus a highly complex undertaking, which is one reason that this is a descriptive paper. Another reason is that not much is known about the relative magnitude of these pathways. Therefore, the first major purpose of this paper is to describe the multitude of pathways to exit from the labour force in an institutional setting with a very broad range of available programs. This type of knowledge is important in research and as mentioned in policy discussions about reforms of welfare and retirement programs in a setting with big demographic changes in the future age composition of the population in the rich OECD countries. Furthermore policies to promote higher participation and employment rates among the seniors in the labour force also depend on more solid evidence about the withdrawal process from the labour force. The second major purpose of the paper is to estimate how individuals allocate into different pathways out of the labour force conditional on early retirement.

In Section 2 we describe briefly the pathways from work to retirement programs and the main retirement programs in Denmark. As part of this, we also describe briefly the income compensating programs which enter into some of the pathways in different combinations. Next, Section 3 draws on a register based panel data set for the period 1984-2000 to describe the actual distribution on a number of pathways from work to retirement for people who retire early during this period. Section 4 describes the data set, being a 10 per cent panel sample of the Danish population 18-66 years old followed during the period from 1984 and on. Further, Section 4 introduces the empirical model, which is a multinomial logit estimation of the allocation of individuals in the sample to different pathways, including the outcome of being still in the labour force in the year in question as the group of reference. In Section 5 we present the results from the estimations and illustrate them by calculating predicted probabilities of early retirement at different ages and through different pathways for a number of specific groups in the labour force. Section 6 concludes the paper. 


\section{Pathways, retirement and social security programs}

In this section we describe briefly the three main components in the analysis. The pathway from the last job to early retirement can be simple, i.e. a transition from a job to retirement or it can consist of a spell collecting one type of benefits or a sequence of spells combining different social security programs. Next, we describe the main retirement programs in Denmark and the main social security programs which provide an income for people on a pathway between the last job and early retirement.

\subsection{Pathways}

In principle, a big number of combinations are possible as pathways from an ordinary full-time job to a retirement program. It turns out however that a fairly small number of simple or composite pathways dominate the retirement process. In the next section we turn to a description of these pathways based on our panel data for the years since 1984 . One further possibility to bridge an eventual gap between a full-time job and exit from the labour market is a shift to part-time work as a "bridge" job. Unfortunately, we are unable to identify a shift to a part-time job in our micro database ${ }^{1}$ and therefore, information about the extent of "bridge" jobs is solely obtained from earlier studies. We identify eight different pathways to early retirement from the labour market

- One possibility is obviously to retire from a job as a wage earner or from being self-employed in one's own business. In the econometric analyses in Section 5 these two pathways are aggregated to one, i.e. early retirement from employment.

- Next, we identify two pathways used by people out of employment but with a close labour force attachment who are provided for by unemployment insurance benefits (UIB) and to a lesser extent by sickness benefits (SB) up to the time of early retirement. These two pathways are aggregated to one, called "UIB dominated pathways", in the econometric analyses below.

- Another pathway is defined by social welfare benefits (SWB) being the dominant income up to the time of early retirement. Further, two pathways are defined by combinations of SWB, SB and UIB as the main sources of income

\footnotetext{
${ }^{1}$ Usable information is either not available or of bad quality.
} 
until early retirement. Finally, we identify a residual pathway. These four individual pathways are aggregated to one, called "other pathways", in the econometric analyses below.

\subsection{Retirement programs ${ }^{2}$}

The Danish pension and retirement system consists of a number of public sector programs and private arrangements. In this section, the destinations outside the labour force applied in the paper are described briefly. The major exit routes from the labour market are the many programs either explicitly for early retirement or programs containing an early retirement option. It should be emphasized that some of these can be chosen freely if objective conditions for eligibility are fulfilled while others are open only after visitation on either medical or social criteria. The different programs are the following ${ }^{3}$ :

\section{(1) Social Disability Pension (SDP, Førtidspension)}

Eligibility for SDP depends on an application being decided upon relative to a set of medical and social criteria. SDP is thus not an individual option like eligibility for e.g. labour market pension from a specific age. Until 2003 the SDP system was quite complex as the rules differed regarding tax treatment and regarding the means testing or not of the different components and amounts that made up the program. From 2003 there are only two levels of SDP benefits for new entrants to the program with the level depending on marital status.

\section{(2) Post Employment Wage (PEW, Efterløn)}

In contrast to the SDP the PEW scheme introduced in 1979 provides the possibility of early retirement from age 60 without having to fulfil any health criteria. To become eligible for PEW an individual is required to have been in an unemployment insurance fund for 25 out of the last 30 years. PEW can be entered both from employment and from unemployment.

\section{(3) Transitional Benefits Program (TBP, Overgangsydelse)}

This program was introduced in 1992 and entry to the program was extended in 1994. Eligible persons for entry were initially 55-59 years old members of unemployment

\footnotetext{
${ }^{2}$ A survey for reference of characteristics of the main retirement and social security programs can be found in Table A8 in the Appendix.

${ }^{3}$ A discussion of the ongoing policy reforms in this area can be found in OECD (2000).
} 
insurance funds who had been unemployed for at least 12 out of the most recent 15 months. From the beginning of 1994 the program was extended to cover the age group 50-54 years with the same labour market criteria as for the 55-59 years old group. Benefits were set at 82 per cent of maximum unemployment insurance benefits and the maximum duration was until transition to PEW at the age of 60. Entry to the program was terminated at the beginning of 1996. As a consequence, this program will no longer appear among the possible retirement states as from 2006.

(4) Public Employees Pension Scheme (PEP, Tjenestemandspension) and Labour Market Pensions (LMP), called occupational pensions, are old age pensions that are available with an actuarial discount at an earlier age than 67.

\section{(5) Private Pensions Saving}

Finally, there is a broad coverage with private pension plans, mostly in categories of savings arrangement which until recently have been treated quite favourably by the tax rules. These too, can mostly be taken up from age 60 .

\section{(6) Old age pension (OAP)}

From age 67 everybody are entitled to OAP consisting of a (nearly) universal base amount and a means tested supplementary amount.

\subsection{Social security programs}

In the non-employment related pathways described above people receive an income from one of the social security programs described briefly in the following: ${ }^{4}$

\section{(1) Unemployment Insurance Benefits (UIB)}

Unemployment insurance is voluntary in Denmark. Eligibility to UIB is conditional on at least 1 years membership of an unemployment insurance fund, on a minimum period of former work (52 weeks within 3 years in 2000), and on being available for a job. UIB correspond to 90 per cent of former earnings subject to a ceiling. On average, the compensation for lost earnings is about 65 per cent.

\section{(2) Social Welfare Benefits (SWB)}

Recipients of SWB consist of two groups: a) unemployed who are not eligible to UIB and b) individuals who receive SWB due to problems other than unemployment. In

\footnotetext{
${ }^{4}$ For further information about these programs, see e.g. Lausten (2001), Hansen (2000) and Høgelund (2003).
} 
principle, the duration of SWB is unlimited. Benefits amounts to between 60 and 80 per cent of the ceiling for UIB, cf. above.

\section{(3) Sickness Benefits (SB)}

SB correspond to earnings subject to the same ceiling as for UIB, cf. above. The maximum benefit period is 1 year within 36 months.

\section{The distribution on pathways, 1984-2000}

After the description of the separate pathways in Section 2 we turn to look into the actual flows through these different ways into early retirement. First, as mentioned, shift to a part-time job could be one of the pathways. Ruhm (1990) shows that partial retirement is widespread in the U.S. In the case of Denmark, many individuals, in particular self-employed, express a desire to retire partially at the end of their working lives, cf. Pedersen (1998), Nørregaard (1996) and Pedersen \& Smith (1995). However, paradoxically, the extent of partial retirement through less working hours seems to be limited in Denmark. We are not able to identify shifts to part-time work as bridge jobs to retirement in the present paper. In earlier studies Nørregaard (1996) finds that only relatively few retire through part-time work, flexible working hours etc. Similarly, a survey conducted by the Danish National Institute of Social Research in 1999 shows that only 6 per cent of already retired individuals had reduced their working week gradually through part-time work. Furthermore, very few individuals have joined parttime retirement schemes, cf. Pedersen \& Smith (1995).

Next, we go on to look more closely at the pathways from work to an early retirement program that we can identify in our longitudinal dataset. A first summary overview is shown in Figure 1 below. The figure shows the relative distribution over the whole period 1985-2000 on the pathways through which entry can occur to early retirement. Entry from a job is found to be dominant covering about 65 per cent of all transitions. The two other big pathways from which entry occurs are from unemployment collecting UIB and from a working life as self-employed, which in this case includes assisting spouses. The remaining about 10 per cent of states from which entry occurs are 
combined states where people are being provided for by SWB alone or by UIB, SWB or $\mathrm{SB}$ in a composite sequence. ${ }^{5}$

Figure 1. Distribution on pathways to early retirement, pooled observations, 19852000.

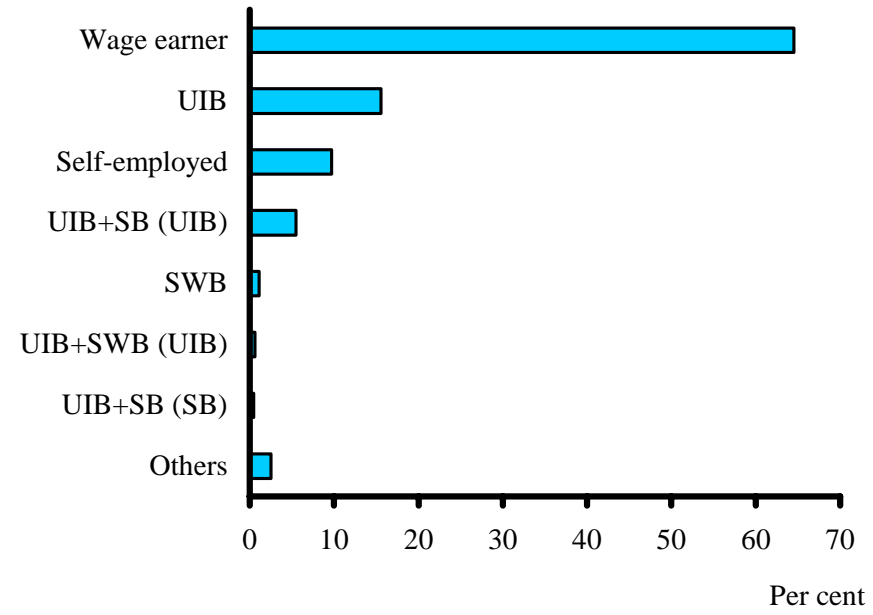

Figure 2. Share of people entering early retirement coming from employment, 19852000.

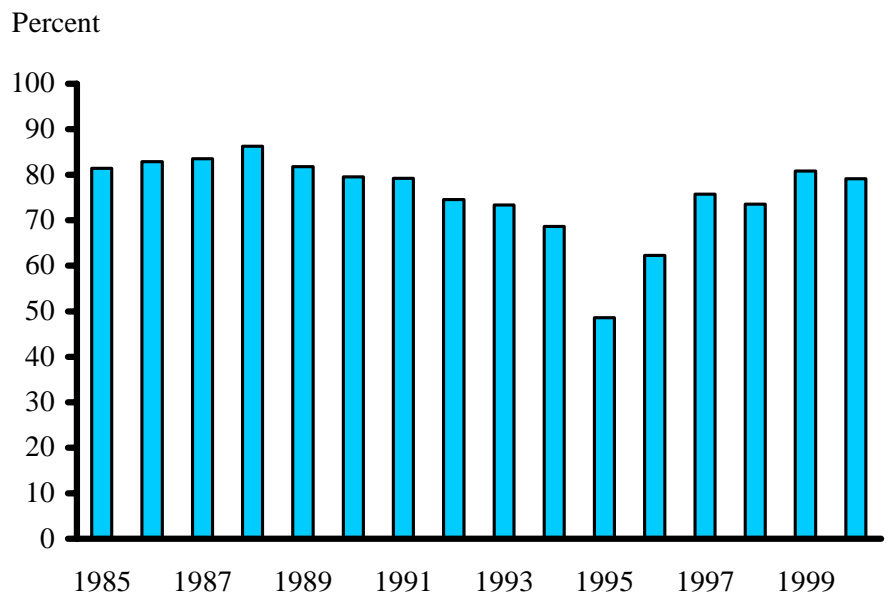

\footnotetext{
${ }^{5}$ The abbreviation in brackets expresses the type of social security benefits from which the largest amount of benefits has been received in the period from work until retirement. For instance, the title "UIB + SB (UIB)" expresses a combination of UIB and SB where UIB is the dominant type of benefits.
} 
In Figure 2 above the focus is on the cyclical impact on the use of pathways by showing the share of people entering early retirement directly from employment, either in a job or as self-employed. Figure 2 is a clear reflection of the cyclical profiles during the period with a long phase of increasing unemployment lasting from 1987 to 1993, followed by a strong cyclical upswing from 1994. On top of that, Figure 2 gives a clear impression of the impact from TBP to which long run unemployment was a condition for entry, with the broadest age criterion, 50 - 59 years, in the period 1994 to 1996. In fact, only half of individuals retiring in 1995 retired directly from employment compared to about 80 per cent in the last half of the 1980's as well as around 2000.

In Figure 3 below the focus is on the profile over time in the states from which people enter early retirement, conditional on entry not being from a job or from working in your own business. UIB alone and in combinations reflects to some extent the Danish business cycle especially for the period since 1994 with a big decline in unemployment. Finally, we find a jump up in the second half of the 1990s in the residual group "Others", which is mainly due to the fact that individuals in leave schemes, which were introduced in 1994, are included in this category.

Figure 3. Relative distribution on pathways to early retirement, non-employed people, 1985-2000.

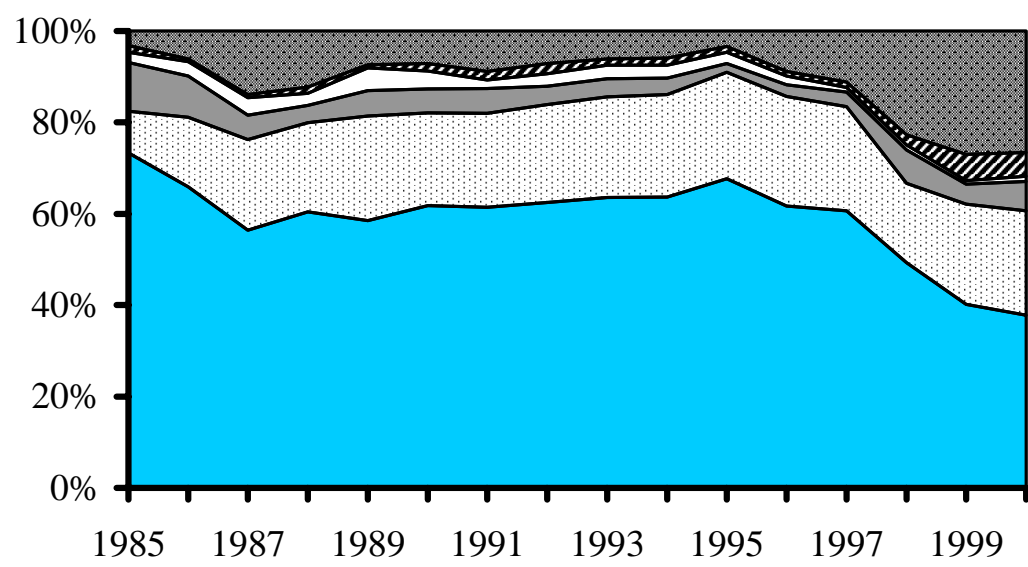

\begin{tabular}{lll}
\hline $\mathrm{UIB}$ & $\square \mathrm{UIB}+\mathrm{SB}(\mathrm{UIB})$ & $\square$ SWB \\
$\square \mathrm{UIB}+\mathrm{SWB}(\mathrm{UIB})$ & $\mathbb{\square} \mathrm{UIB}+\mathrm{SB}(\mathrm{SB})$ & $\square$ Others
\end{tabular}


Next, Figure 4 below shows the average age at entry into early retirement by the three aggregated pathways. For people entering from employment the average age appears to be very stable with a very small decline during the period. The average age for people with a closer labour market attachment, UIB (all), has a very special profile reflecting the natural experiment evident in the temporary opening up of an early exit possibility in form of the TBP, which implied a temporary decline in the average age of early retirement of four years for this group. Finally, the average age for the aggregated pathway, SWB + others, consisting of people with a more loose attachment to the labour force is quite volatile, but without any clear trend.

Figure 4. Average age at early retirement by different pathways, 1985-2000.

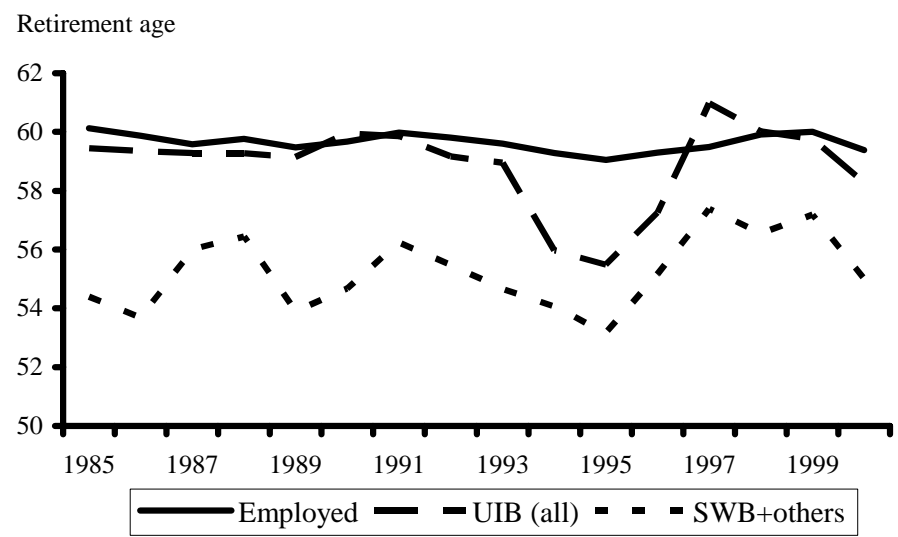

Figure 5 below shows gender differences in pathways to early retirement pooled for the whole period. We find a more than 50 per cent share of women who retire through UIB and UIB in combination with SB. SWB alone or in combination with UIB are on the other hand very male dominated pathways. 
Figure 5. Share of women in the pathways, pooled observations, 1985-2000.

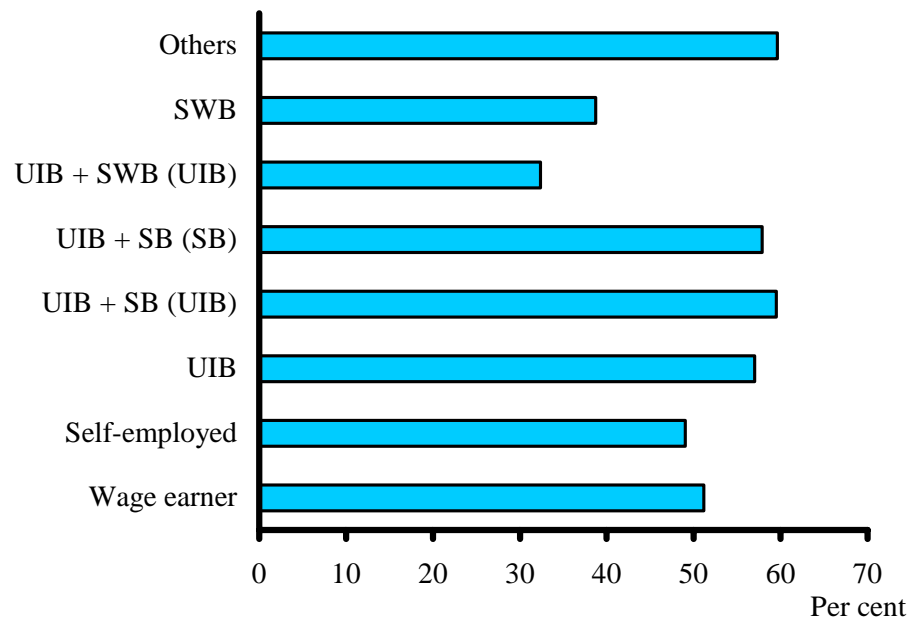

In Figure 6 below we shift the focus to destination states and illustrate how people without a formal education are distributed on retirement programs during the period. The clearest trend is an increasing importance of PEW for this group and a corresponding decrease in the relative importance of the destination state Others+PEP. Further, Figure 6 illustrates very clearly the importance of TBP for people in this educational group.

Figure 6. Early retirement destination states for people without formal education. Per cent, 1985-2000.

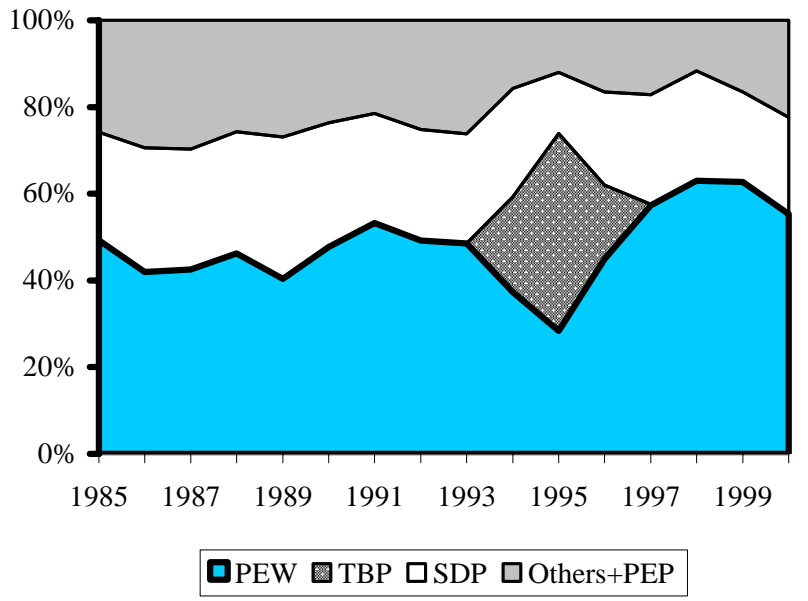


Figure 7. Relative distribution on early retirement destination states for people coming from a) Employment, b) UIB dominated Pathways and c) Other Pathways, per cent, 1985-2000.

a) Employment

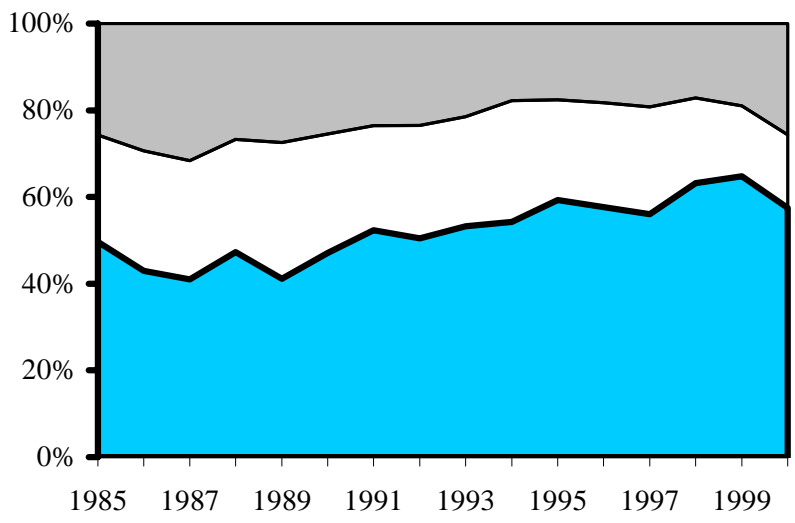

口PEW $\square$ SDP $\square$ PEP+Others

b) UIB dominated Pathways

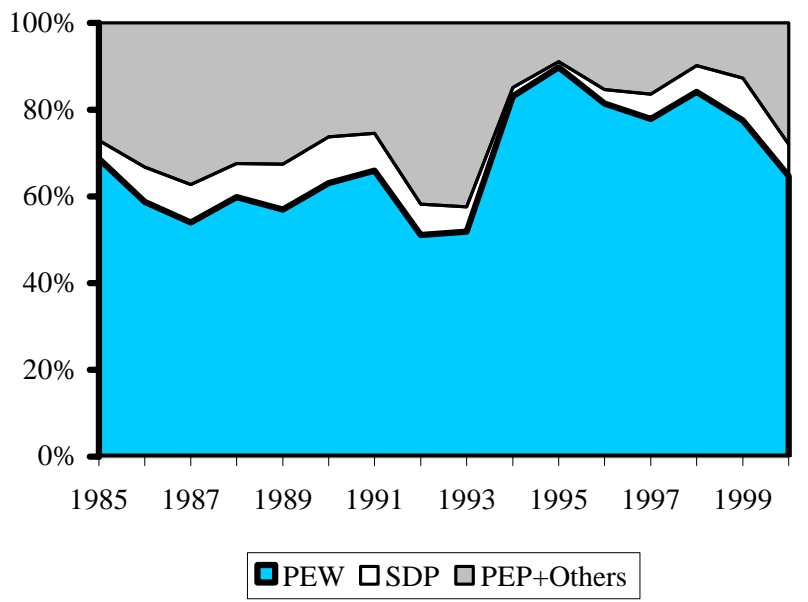


c) Other Pathways

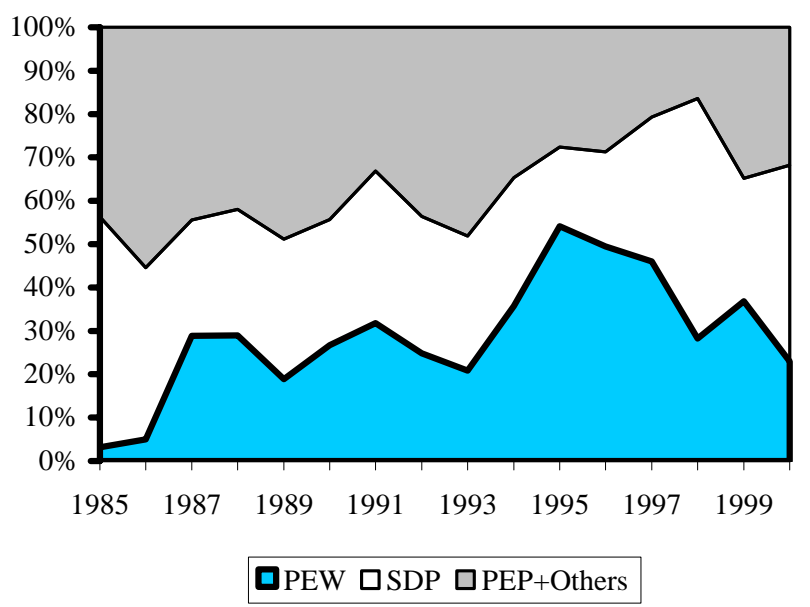

In Figure 7 above we link pathways and destinations by looking at how people who exit by each of the three aggregated pathways are distributed on destinations. In the top panel (a) the main trend is an increasing importance of PEW. In panel (b) PEW is even more important and we observe once again the importance of the temporary opening of the TBP which is aggregated with PEW in the figure. Finally, in panel (c) including the group with the loosest attachment to the labour force we find the same increasing importance of the aggregate PEW destination although as expected at a lower level and with dominance of SDP and Other exit destinations.

Finally, we look in Table 1 below at another aspect of the connection between pathways and destinations focusing on the fact that most of the pathways are fully or dominantly financed by public expenditures. For each of the 5 years preceding early retirement we show the average share of gross income coming from social security benefits in each of the pathways ${ }^{6}$. Using this indicator we find clear differences between the three groups of people for all five years up to early retirement with the biggest difference as expected between the employment pathway and the two other aggregates. Another interesting observation is that the benefit shares even five years back in time seem to be unrelated

\footnotetext{
${ }^{6}$ The sum of PEW, PEP, SDP, TBP, UIB, SWB, SB and benefits for rehabilitation and leave programs. A minor part of the financing comes from labour market contributions and the remaining, dominating part, is financed from general tax revenues.
} 
to the cyclical state of the macro economy which was much better in 2000 than in the two other years.

Table 1. The share of gross income that comes from social security benefits 1-5 years before the early retirement year by aggregate pathways, 1990, 1995 and 2000.

\begin{tabular}{lccc}
\hline & 1990 & 1995 & 2000 \\
\hline Employment & & & \\
t-1 & 0.20 & 0.19 & 0.17 \\
t-2 & 0.14 & 0.16 & 0.16 \\
t-3 & 0.11 & 0.14 & 0.17 \\
t-4 & 0.09 & 0.12 & 0.17 \\
t-5 & 0.10 & 0.12 & 0.15 \\
Max. number of observations ${ }^{\text {a) }}$ & 2846 & 3151 & 3394 \\
& & & \\
UIB Dominated Pathways & & & \\
t-1 & 0.73 & 0.77 & 0.68 \\
t-2 & 0.48 & 0.49 & 0.48 \\
t-3 & 0.34 & 0.37 & 0.35 \\
t-4 & 0.30 & 0.30 & 0.30 \\
t-5 & 0.28 & 0.25 & 0.26 \\
Max. number of observations ${ }^{\text {a) }}$ & 601 & 3027 & 544 \\
& & & \\
Other Pathways & & & \\
t-1 & 0.83 & 0.87 & 0.84 \\
t-2 & 0.68 & 0.65 & 0.75 \\
t-3 & 0.51 & 0.50 & 0.66 \\
t-5 & 0.43 & 0.48 & 0.59 \\
Max. number of observations ${ }^{\text {a) }}$ & 0.39 & 0.44 & 0.50 \\
\hline Notes: a) Number of observations differs slightly for some years due to missing values. &
\end{tabular}

Notes: ${ }^{\text {a) }}$ Number of observations differs slightly for some years due to missing values.

\section{Data and empirical model}

The analyses in this paper draw on longitudinal register data created for administrative purposes. The database consists of a 10 per cent panel sample of the Danish population aged 18-66 years and comprises register-based information on labour market status, receipts of social security, income and labour market and other background characteristics for the period 1984-2000. We restrict the sample to individuals aged 4566 years. This sample, which consists of 243,000 individuals, is representative for the 45-66-year-olds through the whole sample period since new 45-year-olds are added every year. In addition, we restrict the sample to individuals that have been in the labour force at least one year during the period covered by the panel. This condition is fulfilled by 77 per cent of 45-66 years old in our sample, which corresponds to 188,000 individuals. 
In this paper, the date of retirement is the first year an individual is out of the labour force full-time and remains so for the rest of the period covered by the sample. ${ }^{7}$ The criterion of being full-time out of the labour force is determined on the basis of yearly information about the dominant income source.

Yearly information about the primary labour market status by the end of November is applied to determine whether individuals are wage earners, self-employed or temporary out of employment. In the latter case, information about social security benefits is applied to distinguish between recipients of UIB, SB and SWB, cf. Section 2. If individuals are working in the year prior to the retirement year, their status as either wage earner or self-employed is classified as the pathway to early retirement. However, if individuals are temporary out of employment in this year, information about labour market status two years prior to the retirement year is taken into account. Similarly, information three years prior to this year is taken into account if individuals are also temporary out of employment the second year and so on until five years prior to the retirement year. If information is left-censored, information for the available years is applied. Since the two most dominant types of social security benefits for each individual on average constitute almost 100 per cent of total benefits per year, only two types of benefits per year are included when the pathways are identified. In cases where pathways include two types of benefits, the dominant type is identified. The dominant type is defined as the type of benefits from which the largest amount has been received in the period from work until retirement.

Seven pathways account for almost 98 per cent of the transitions to permanent exit from the labour force. The remaining pathways are included in a residual category "Others", cf. Section 3. In the analyses, these eight pathways are aggregated up to three pathways. Individuals who are not yet retired the year in question are chosen as the reference category.

Results of previous studies emphasize the importance of distinguishing between exit states in the analysis of the retirement decision, see e.g. Pedersen \& Smith (1996) and Dahl et al. (2000). Therefore, a multinomial logit (MNL) model for the pathways from

\footnotetext{
7 As stated in Palme \& Svensson (2002) an obvious problem with this way of measuring date of retirement is that workers who are regarded as retired could in fact have returned to the labour market after the last year included in the data. Therefore, on average, the date of retirement will be underestimated. As retirement or early retirement is predominantly an absorbing state, we expect this problem to be of minor empirical relevance.
} 
work to early retirement is estimated for selected years. The MNL approach has also been applied in a number of previous studies of pathways to retirement; see e.g. Riphahn (1997), Hernæs et al. (2000) and Dahl et al. (2000, 2003).

The probabilities in a MNL model in which there are $J+1$ choices for a decision maker $i$ with characteristics $x$ can be written as

$\operatorname{Prob}\left(Y_{i}=j\right)=\frac{e^{\beta^{\prime}{ }_{j} x_{i}}}{\sum_{k=0}^{J} e^{\beta^{\prime}{ }_{k} x_{i}}} \quad$ for $j=0,1,2, \ldots \ldots .$.

The MNL estimator treats each category as distinct but of equal rank. Independence from irrelevant alternatives (IIA) is assumed. The MNL model is a choice model. However, the pathways in focus in the present paper are a mixture of choices and risks. Therefore, in this case the MNL approach is applied simply to expand the two-way correlations in Section 3 to multivariate analyses of the characteristics of individuals that retire through each of the three pathways compared to individuals still remaining in the labour force.

Significant gender differences are found in the decision to retire early in Denmark as well as in other countries, see e.g. Pedersen \& Smith (1996), Danø et al. (1998, 2000), Christensen \& Datta Gupta (2000) and Dahl et al. (2000, 2003). Therefore, separate analyses for men and women are conducted. Denmark is particularly suitable for the study of gender differences in retirement behaviour because the participation rate for women is high compared to the rate in most other countries outside Scandinavia. A number of explanatory variables are included in the analysis, namely age, being an immigrant, cohabitation status, education, wealth and industry. ${ }^{8}$ For descriptive statistics for these variables, see Table A.1 in the Appendix.

Age is entered as an interval variable, i.e. 46-49 years, which is the reference category, 55-59 years, which is the relevant age interval for TBP during the whole period from

\footnotetext{
${ }^{8}$ Initially, the compensation rate was also included as an explanatory variable. However, neither structural nor with respect to interpretation did this variable make sense. First, since we look at a mixture of pathways of which some are choices while others reflect exclusion, we focus on who and not why individuals enter different pathways. Second, the benefit levels are the same within the non-employment groups and therefore, the compensation rate is less interesting in these cases. Consequently, this variable was excluded from the analysis.
} 
1992 to 1996, and 50-54 years, which is relevant relative to TBP in the period 1994 to 1996. The interval variable 60-66 years is relevant relative to PEW. In other words, the results for the age variables give an impression of the importance of availability and/or generosity of retirement programs. ${ }^{9}$ A dummy variable is set equal to one for people being immigrants. ${ }^{10}$ Cohabitation status is also entered as a dummy variable which is set equal to one for single people. ${ }^{11}$ Education is divided into three categories: no qualifying education, vocational education and higher education. Dummy variables for vocational and higher education respectively are entered while no qualifying education is the reference category. Wealth is entered as a continuous variable and converted into millions of Danish kroner in 1984-prices. The variable wealth captures only taxable/registered wealth. The wealth tax which was abolished by the end of 1996 had a fairly high tax-exempt base level of wealth. Furthermore, the accrual of pension wealth is not registered in the administrative data on which our sample is based. As a consequence, this variable is a somewhat imperfect measure of true wealth.

In order to get an idea about the importance of the business cycle, a continuous variable for the unemployment rate in the county in year $\mathrm{t}-1$ is entered. ${ }^{12}$ Dummy variables for the most recent industry of occupation within the last 5 years are entered. We construct 5 categories of industries with employment in the public sector as the reference category. The remaining categories are "primary or secondary industries", "wholesale, retail, hotels and restaurants”, “transportation, postal and telegraph services, financing and private services" and finally, "non-employed or information about industry missing”. The latter category is supposed to give an idea about the importance of nonemployment within the last 5 years. However, industrial information is in some cases missing for self-employed which might contribute to underestimate the importance of non-employment within the last 5 years since self-employed and non-employed are

\footnotetext{
${ }^{9}$ Finer age intervals would have made it possible to better see the age pattern. However, disaggregation in neither one-year nor two-year intervals is possible due to small sample size for "other pathways".

${ }^{10}$ It would have been optimal to distinguish between Western and non-Western immigrants since the labour market situation for these two groups differ to a large extent. Unfortunately, however, since for most years, our sample contains less than 20 immigrants in each of the two groups UIB dominated pathways and "other pathways", further disaggregation of the immigrant variable is not possible.

${ }^{11}$ It would have been informative to split the group of singles by divorced, widowed and other singles. However, information on divorced and widowed is not available in the dataset.

${ }^{12}$ Counties are chosen rather than municipalities because typically Danish municipalities are fairly small. In fact, around 60 per cent of all individuals live in municipalities with less than 40,000 inhabitants. Therefore, the mobility across boundaries is considerable for which reason the unemployment rate at the municipality level is assumed to be less important.
} 
found in two different pathway categories. On the other hand, however, the construction of the industry variable is based on information for the end of November. That is, if individuals are employed during the year but not by the end of November, this information is not captured by the industry variable leading to overestimating the importance of non-employment within the last 5 years. However, to be employed in particular seasons (excluding November) every year during a five year period is assumed to have a low incidence.

\section{Results}

In the appendix Tables A2-A7 we show the results separately for men and women and for the years 1990, 1995 and 2000 from estimating the multinomial logit model and calculating marginal effects for the allocation to three aggregate pathways out of the labour force. Those in the sample who are not yet retired by the year in question are the reference group relative to the interpretation of the results reported in Tables A2-A7.

In general, the most pronounced effects are as expected found for the age variables. In fact, relatively large marginal effects ${ }^{13}$ are found for age for men as well as women for the employment and the UIB dominated pathways across 1990, 1995 and 2000 suggesting that availability and/or generosity of retirement programs play a dominating role when individuals retire through these pathways. This result applies to women in particular. Retirement through PEW seems to be important independently of the cyclical situation. In 1995 the TBP was open and this is seen as expected to have a strong impact on the retirement probability through the UIB dominated pathways, especially for women. For both women and men the marginal effect from being aged 55 - 59 increased in 1995 to the same level as for the 60 - 66 years old when we consider the UIB dominated pathways. Thus, the program impact was very strong.

The marginal effects from the age variables are small for the "other pathways" group. The group is composed of persons in different programs before entry to retirement making it somewhat complicated to interpret the effects in the estimations. Once again, there is an impact from the TBP which was open in 1995.

\footnotetext{
${ }^{13}$ The size of marginal effects is difficult to interpret across pathways due to the big difference regarding volume. Therefore, we only focus on the relative size of these effects within each of the three groups of pathways.
} 
As regards the remaining explanatory variables, marginal effects are either fairly small in general or only relatively large for individuals retiring through "other pathways". The latter result is found for all three years for women and for 1990 and 2000 for men for one of the industry controls that are entered with public sector employment as the excluded category, namely the "non-employed/ information about industry missing" category. For individuals retiring through "other pathways”, it seems reasonable to assume that this sector variable typically indicates non-employment rather than selfemployment, see also Section 4. The lack of information regarding employment for the preceding 5 years seems to become relatively more important through time, especially for women, probably reflecting that this becomes a more selected group, dominated by non - employment or employment in marginal jobs, after 5 years of cyclical upswing between 1995 and 2000.

With the reservation in mind that there are rather few immigrants in the sample, cf. Section 4, a relatively large positive marginal effect is found for being a male immigrant retiring through UIB dominated and “other pathways” in the second half of the 1990s. On the other hand the coefficient to the immigrant variable is insignificant for the Employment pathway. In other words, not surprisingly, immigrants are in particular found to retire early through the pathways reflecting the most loose attachment to the labour market. The share of immigrants aged 45-66 years increased during the sample period which probably explains that being an immigrant is only found to be important in 1995 and 2000. The coefficient to being a female immigrant are insignificant in 1990 and 2000, while relatively high marginal effects in 1995 relative to UIB dominated pathways and “other pathways” presumably reflects the impact from TBP for these groups of workers.

Being single has a significant impact for men increasing the probability for retirement through all pathways, except the employment related in 1995. Looking at the marginal effects, they tend to be of the same magnitude as what we find for being an immigrant. In accordance with prior expectations, having a higher education implies a significantly lower probability for early exit from the labour force. The variable is however insignificant for the group of “other pathways” in 1990 which most probably reflects that very few highly educated people were leaving the labour force through those pathways at that time. 
The coefficient to wealth is significantly negative regarding all pathways except the UIB dominated pathways for women in 1995. It will however, based on the negative sign, be premature to conclude that the ongoing building up of pension assets will result in later retirement per se as pension wealth obviously correlates with other important retirement age determinants.

Looking at the local unemployment rate we find a significant positive impact in 1995 and 2000 in accordance with prior expectations. The different 1990 results probably reflects that this was a year of very high and fairly evenly distributed unemployment while 1995 was the initial phase of a cyclical upswing of which 2000 was a peak with a higher relative variation in regional unemployment rates.

To illustrate the numeric size of the retirement probabilities for individuals with specific properties we have calculated the predicted probabilities from the probit estimation reported in Tables A2-A7 and show the results in Tables 2 and 3 separately for men and women.

The range in the predicted probabilities is very big, i.e. from close to nil for exit through “other pathways” for people in their early 50s to 25-30 per cent annual probability for for exit through employment related pathways for the 60 - 66 years old unskilled women, native born as well as immigrants, with a work history in the public sector.

Generally, the predicted probabilities are higher at all ages and pathways for unskilled, for immigrants, for people living single and for people with a work history in the public sector. Taking the year 2000 as an example and looking at the 60 - 66 years group exiting through employment related pathways we find a range for men between 10 per cent for higher educated and 20 per cent for the unskilled with people with a vocational education being in between having an exit probability around 15 per cent. For women the corresponding exit probabilities are all about 5 percentage points higher.

For individuals in the 50s the impact from the TBP in 1995 is evident when looking at the probabilities which for unskilled and for people with vocational education are many times higher in 1995 than in the years before and after the program. This pattern is not found for people with higher education as the risk of experiencing long-term unemployment - the condition for entry to TBP - is much lower in this group. 
Table 2. Predicted probabilities for early retirement through different pathways for five different profiles, by age group, year, education, family status and previous sector of employment, men. Percent.

\begin{tabular}{|c|c|c|c|c|c|c|c|c|c|}
\hline & \multicolumn{3}{|c|}{ Employment } & \multicolumn{3}{|c|}{ UIB dominated pathways } & \multicolumn{3}{|c|}{ Other pathways } \\
\hline & 1990 & 1995 & 2000 & 1990 & 1995 & 2000 & 1990 & 1995 & 2000 \\
\hline $\begin{array}{l}\text { a. cohabiting, no formal } \\
\text { education, public sector. }\end{array}$ & & & & & & & & & \\
\hline Aged $50-54$ & 0.81 & 1.24 & 1.23 & 0.16 & 2.34 & 0.10 & 0.04 & 0.40 & 0.16 \\
\hline Aged 55-59 & 1.73 & 2.09 & 1.38 & 0.27 & 3.96 & 0.13 & 0.03 & 0.33 & 0.12 \\
\hline Aged 60-66 & 14.48 & 17.03 & 17.74 & 3.68 & 3.43 & 1.72 & 0.12 & 0.23 & 0.23 \\
\hline $\begin{array}{l}\text { b. Immigrant, cohabiting, } \\
\text { no formal education, } \\
\text { public sector. }\end{array}$ & & & & & & & & & \\
\hline Aged 50-54 & 1.07 & 1.13 & 1.55 & 0.35 & 3.33 & 0.18 & 0.10 & 0.93 & 0.47 \\
\hline Aged 55-59 & 2.28 & 1.92 & 1.76 & 0.59 & 5.67 & 0.23 & 0.07 & 0.77 & 0.36 \\
\hline Aged 60-66 & 17.40 & 15.65 & 21.13 & 7.28 & 4.92 & 2.84 & 0.25 & 0.53 & 0.64 \\
\hline c. single, no formal & & & & & & & & & \\
\hline $\begin{array}{l}\text { Aged 50-54 } \\
\text { Aged 55-59 }\end{array}$ & $\begin{array}{l}1.15 \\
2.53\end{array}$ & $\begin{array}{l}1.19 \\
2.01\end{array}$ & $\begin{array}{l}1.53 \\
1.73\end{array}$ & $\begin{array}{l}0.39 \\
0.22\end{array}$ & $\begin{array}{l}3.07 \\
5.19\end{array}$ & $\begin{array}{l}0.17 \\
0.22\end{array}$ & $\begin{array}{l}0.19 \\
0.16\end{array}$ & $\begin{array}{l}0.96 \\
0.78\end{array}$ & $\begin{array}{l}0.45 \\
0.34\end{array}$ \\
\hline Aged 60-66 & 18.32 & 16.43 & 20.96 & 7.88 & 4.51 & 2.71 & 0.48 & 0.54 & 0.62 \\
\hline $\begin{array}{l}\text { d1cohabiting, vocational } \\
\text { education, primary or } \\
\text { secondary industries. }\end{array}$ & & & & & & & & & \\
\hline Aged 50-54 & 0.58 & 0.80 & 1.02 & 0.09 & 1.58 & 0.14 & 0.04 & 0.13 & 0.13 \\
\hline Aged 55-59 & 1.23 & 1.36 & 1.17 & 0.16 & 2.70 & 0.19 & 0.03 & 0.11 & 0.10 \\
\hline Aged 60-66 & 10.71 & 11.63 & 15.04 & 2.17 & 2.45 & 2.48 & 0.12 & 0.08 & 0.19 \\
\hline $\begin{array}{l}\text { d2. cohabiting, } \\
\text { vocational education, } \\
\text { public sector. }\end{array}$ & & & & & & & & & \\
\hline Aged 50-54 & 0.70 & 1.14 & 1.20 & 0.13 & 1.98 & 0.14 & 0.03 & 0.27 & 0.13 \\
\hline Aged 55-59 & 1.50 & 1.95 & 1.35 & 0.22 & 3.37 & 0.18 & 0.02 & 0.22 & 0.10 \\
\hline Aged 60-66 & 12.76 & 15.94 & 17.30 & 3.00 & 2.93 & 2.35 & 0.09 & 0.15 & 0.19 \\
\hline $\begin{array}{l}\text { e1. cohabiting, higher } \\
\text { education, private service } \\
\text { sector }\end{array}$ & & & & & & & & & \\
\hline Aged 50-54 & 0.34 & 0.44 & 0.70 & 0.01 & 0.27 & 0.06 & 0.02 & 0.02 & 0.06 \\
\hline Aged 55-59 & 0.74 & 0.73 & 0.77 & 0.02 & 0.46 & 0.08 & 0.02 & 0.01 & 0.04 \\
\hline Aged 60-66 & 6.38 & 6.62 & 10.68 & 0.26 & 0.44 & 1.08 & 0.06 & 0.01 & 0.08 \\
\hline $\begin{array}{l}\text { e2. cohabiting, higher } \\
\text { education, public sector. } \\
\text { Aged 50-54 }\end{array}$ & 0.35 & 0.53 & 0.71 & 0.03 & 0.63 & 0.06 & 0.02 & 0.05 & 0.07 \\
\hline Aged 55-59 & 0.72 & 0.91 & 0.79 & 0.06 & 1.09 & 0.07 & 0.01 & 0.04 & 0.05 \\
\hline Aged 60-66 & 6.73 & 8.00 & 10.97 & 0.83 & 1.02 & 1.02 & 0.06 & 0.03 & 0.10 \\
\hline Number of observations & 52066 & 56902 & 55493 & 52066 & 56902 & 55493 & 52066 & 56902 & 55493 \\
\hline
\end{tabular}

Note: For all five profiles for the year in question, the base value for unemployment rate in the county in year t- 1 is set equal to the overall mean, while the base value for wealth is set equal to the mean for the particular profile. 
Table 3. Predicted probabilities for early retirement through different pathways for five different profiles, by age group, year, education, family status and previous sector of employment, women. Percent.

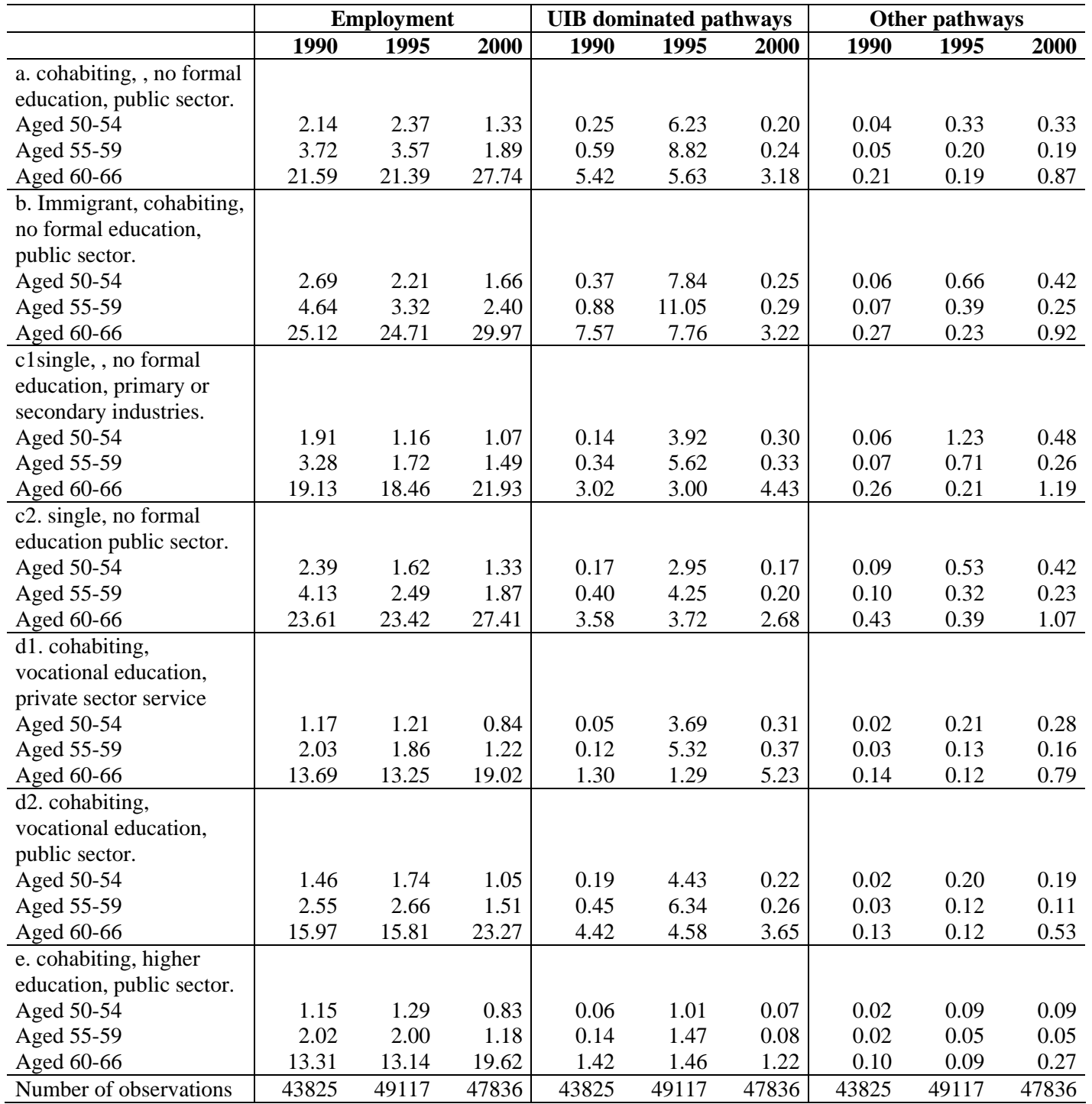

Note: For all five profiles for the year in question, the base value for unemployment rate in the county in year t- 1 is set equal to the overall mean, while the base value for wealth is set equal to the mean for the particular profile.

\section{Conclusions}

The purpose of this paper is to describe and analyse the multitude of pathways to exit from the labour force. We focus on the pathways leading to exit from the labour force into a program for early retirement. Eight pathways from work to an early retirement program are identified. Entry from a job is dominant covering almost 2/3 of all transitions. The two other big states from which entry occurs are from unemployment 
collecting UIB and from a working life as self-employed. The remaining about 10 per cent of the pathways are states where people with different degrees of attachment to the labour force are being provided for by SWB alone or by UIB in combinations with SWB or SB. Gender differences are present regarding these pathways. The majority of those who retire through unemployment dominated pathways are women, while pathways dominated by SWB shows a majority of men.

The share of people who have retired directly from employment, whether wage earners or self-employed, clearly reflects the cyclical profile since the middle of the 1980s. Further, this share is exceptionally low in the middle of the 1990s due to the temporary opening up of an early exit possibility in form of the TBP scheme, which was available for unemployment insured who had been long-term unemployed. Focusing on early retirement from non-employment, the share of retired through pathways including UIB reflects also to some extent the Danish business cycle in the sample period.

The eight pathways fall into three groups. One group is transitions directly from employment for which the main trend regarding destination is an increasing importance of PEW over time. Another group is the pathways dominated by UIB for whom PEW is even more important. Further, the TBP is an important destination for this group. Finally, the last group is dominated by benefits reflecting a low attachment to the labour force in the period prior to transition to early retirement. For this group of pathways called "other pathways" the same increasing importance of the aggregate PEW destination is observed although unsurprisingly at a lower level and with dominance of SDP and Other exit destinations.

Looking at the average share of gross income coming from social security benefits for each of the 5 years preceding early retirement we find a clear difference between the three groups of pathways for all five years with the biggest difference between the employment pathway and the non-employment pathways. Further, we find that the benefit shares even five years back in time surprisingly seem to be unrelated to the cyclical state of the macro economy.

We analyze the interaction between a big number of background variables and use of the three aggregated pathways by estimation of a multinomial logit model for selected years with those in the sample who are not yet retired by the year in question as the reference group. Our approach is descriptive trying to judge the importance of different 
background factors relative to the use of pathways with a focus also on differences by gender. The pathways differ in a qualitative sense as the employment pathway is choice based while the non-employment pathways can be used only conditional on fulfilling the criteria for collecting benefits, be it UIB, SB or SWB. Due to this, an optimising approach is outside the scope of the present paper.

Turning to the estimation results, a number of background variables have the same impact across all or nearly all pathways and years. This is the case for having a higher education and for wealth which for higher values reduce the probability of using these pathways. The opposite, systematic positive impact on use of these pathways is found for people aged 60-66 years, for single men and for people with an indicator for missing industrial information.

Other background variables show more variation in their impact, mostly consistent with prior expectations. The local unemployment rate has as expected a systematic positive impact on the use of all three pathways but only in 1995 and 2000 which might reflect a high relative unemployment rate for older workers in these years. The results reflect strongly the fact that the TBP was open in 1995, i.e. we find a significant positive impact for people aged 50-54 and 55-59 years on the use of all three pathways.

Overall, the results suggest that availability and/or generosity of retirement programs as reflected in the marginal effects from the age variables, are very important for early retirement through the employment and UIB dominated pathways while individual background factors are of minor importance. This result applies in particular to women. For early retirement through "other pathways", however, personal characteristics seem to be at least as important as retirement programs when looking at the marginal effects from age variables relative to other individual factors.

The transition from work to retirement is complex and far from the conventional idea of exit typically occurring from a job at the official pension age. An interesting approach in future work would be to have access to health data making it possible to build a competing risks model where some pathways are used due to health shocks and others are chosen based on economic optimisation comparing compensation rates with disutility from continued work. 


\section{References}

Christensen, B.J. \& Datta Gupta, N. (2000) The Effect of a Pension Reform on the Retirement of Danish Married Couples (in Danish). Nationaløkonomisk Tidskrift, 138, pp. 222-242.

Dahl, S.Å., Nilsen, Ø.A. \& Vaage, K. (2000) Work or retirement? Exit routes for Norwegian elderly. Applied Economics, 32, pp. 1865-1876.

Dahl, S.Å., Nilsen, Ø.A. \& Vaage, K. (2003) Gender differences in Early Retirement Behaviour, European Sociological Review, Vol. 19, No. 2, 179-198.

Danø, A.M., Ejrnæs, M. \& Husted, L. (1998) Gender Differences in Retirement Behaviour, Institute of Local Government Studies - Denmark, Copenhagen.

Danø, A.M., Ejrnæs, M. \& Husted, L. (2000) How is the Retirement Age Affected by the Reform of the Post Employment Wage program? (in Danish), Nationaløkonomisk Tidsskrift, 138, pp.205-221.

Hansen, H. (2000) Elements of Social Security. A comparison covering: Denmark, Sweden, Finland, Austria, Germany, The Netherlands, Great Britain and Canada. The Danish National Institute of Social Research 00:7. Copenhagen.

Hernæs, E., Sollie, M. \& Strøm, S. (2000) Early retirement and Economic Incentives. Scandinavian Journal of Economics 102(3), 481-502.

Høgelund, J. (2003) In Search of Effective Disability Policy. Comparing the Development and Outcomes of Dutch and Danish Disability Policies. Amsterdam University Press.

Kohli, M. \& Rein, M (1991) The changing balance of work and retirement, in Time for Retirement Comparative Studies of Early Exit from the Labour Force (Eds.) M. Kohli, M. Rein, A.M. Guillemard \& H.v. Gunstern, Cambridge University, pp. 1-35.

Lausten, M. (2001) Transfer Incomes and Income Distribution (in Danish). AKF Report. Copenhagen.

Nørregaard, C. (1996) Work and Retirement in the Nineties - and Retired Persons in the Future (in Danish). Copenhagen: Socialforskningsinstituttet.

OECD (2000) Employment Outlook. Paris.

OECD (2003) Employment Outlook. Paris.

Palme, M. \& I. Svensson (2003). Income Security Programs and Retirement in Sweden. Ch. 10 in J. Gruber \& D. Wise (eds.) Social Security Programs and retirement around the World. NBER. Chicago University Press.

Pedersen, P.J. (1998) The Elderly and the Labour Market, in Smith, N. (ed) Work, Work Incentives and Unemployment (in Danish), Aarhus, pp. 151-178.

Pedersen, P.J. \& Smith, N. (1995) The Retirement Decision, in Mogensen, G.V. (ed) Work Incentives in the Danish Welfare State, New Empirical Evidence, The Rockwool Foundation Research Unit, Aarhus.

Pedersen, P.J. \& Smith, N. (1996) A Duration Analysis of the Decision to Retire Early, in Wadensjö, E. (ed.) The Nordic Labour Markets in the 1990's, Amsterdam, pp. 31-68.

Riphahn, R. T. (1997) Disability retirement and unemployment - substitute pathways for labour force exit? An empirical test for the case of Germany, Applied Economics, 29, pp. 551-61. 
Ruhm, C.J. (1990) Bridge Jobs and Partial Retirement. Journal of Labor Economics, vol. 8, no. 4.

\section{Appendix}

Table A.1. Descriptive statistics, men and women, 2000.

\begin{tabular}{|c|c|c|c|c|}
\hline & \multirow{2}{*}{$\begin{array}{l}\text { Men } \\
\text { Means } \\
\end{array}$} & \multicolumn{3}{|c|}{ Women } \\
\hline & & Std. err. & Means & Std. err. \\
\hline \multicolumn{5}{|l|}{ Age } \\
\hline Aged 50-54 & 0.32 & $(0.47)$ & 0.35 & $(0.48)$ \\
\hline Aged 55-59 & 0.28 & $(0.45)$ & 0.27 & $(0.44)$ \\
\hline Aged 60-66 & 0.15 & $(0.36)$ & 0.11 & $(0.32)$ \\
\hline Immigrant & 0.04 & $(0.21)$ & 0.04 & $(0.20)$ \\
\hline Single & 0.20 & $(0.40)$ & 0.24 & $(0.43)$ \\
\hline \multicolumn{5}{|l|}{ Education } \\
\hline Vocational training & 0.44 & $(0.50)$ & 0.37 & $(0.48)$ \\
\hline Higher education & 0.25 & $(0.43)$ & 0.27 & $(0.44)$ \\
\hline Wealth in 1,000,000 d.kr., 1984-prices & 0.80 & (3.99) & 0.38 & $(2.45)$ \\
\hline Unemployment rate in the county in year $t-1$ & 5.35 & $(1.18)$ & 5.33 & $(1.18)$ \\
\hline \multicolumn{5}{|l|}{ The most recent industry within 5 years } \\
\hline Primary or secondary industries & 0.35 & $(0.48)$ & 0.12 & $(0.33)$ \\
\hline Wholesale, retail, hotels, restaurants & 0.13 & $(0.34)$ & 0.11 & $(0.31)$ \\
\hline $\begin{array}{l}\text { Transportation, postal and telegraph services, } \\
\text { financing and private services } \\
\text { Non-employed/ information about industry }\end{array}$ & 0.21 & $(0.41)$ & 0.14 & $(0.35)$ \\
\hline Missing & 0.06 & 0.23 & 0.07 & $(0.26)$ \\
\hline Number of observations & \multicolumn{2}{|c|}{55493} & \multicolumn{2}{|c|}{47836} \\
\hline
\end{tabular}


Table A2. Multinomial logit estimates and marginal effects of determinants of early retirement through different pathways, men, 1990 (standard errors in parentheses).

\begin{tabular}{|c|c|c|c|c|c|c|}
\hline Variable & Employmen & & UIB domir & ed pathways & Other path & ays \\
\hline Aged 50-54 & $\begin{array}{l}\text { Coefficient } \\
0.696^{* * *} \\
(0.173)\end{array}$ & $\begin{array}{l}\text { Marg. effect } \\
0.0074\end{array}$ & $\begin{array}{l}\text { Coefficient } \\
1.071^{*} \\
(0.459)\end{array}$ & $\begin{array}{l}\text { Marg. effect } \\
0.0017\end{array}$ & $\begin{array}{l}\text { Coefficient } \\
0.332 \\
(0.335)\end{array}$ & $\begin{array}{l}\text { Marg. effect } \\
0.0002\end{array}$ \\
\hline Aged 55-59 & $\begin{array}{l}1.470^{* * *} \\
(0.158)\end{array}$ & 0.0213 & $\begin{array}{l}1.607 * * * \\
(0.438)\end{array}$ & 0.0032 & $\begin{array}{l}0.021 \\
(0.385)\end{array}$ & -0.0000 \\
\hline Aged 60-66 & $\begin{array}{l}3.783 * * * \\
(0.139)\end{array}$ & 0.1558 & $\begin{array}{l}4.397 * * * \\
(0.387)\end{array}$ & 0.0344 & $\begin{array}{l}1.574 * * * \\
(0.304)\end{array}$ & 0.0015 \\
\hline Immigrant & $\begin{array}{l}0.252 \\
(0.178)\end{array}$ & 0.0025 & $\begin{array}{l}0.749^{*} \\
(0.297)\end{array}$ & 0.0013 & $\begin{array}{l}0.750 \\
(0.386)\end{array}$ & 0.0007 \\
\hline Single & $\begin{array}{l}0.322^{* * *} \\
(0.072)\end{array}$ & 0.0031 & $\begin{array}{l}0.847 * * * \\
(0.133)\end{array}$ & 0.0013 & $\begin{array}{l}1.435^{* * *} \\
(0.237)\end{array}$ & 0.0016 \\
\hline Vocational training & $\begin{array}{l}-0.152^{*} \\
(0.064)\end{array}$ & -0.0013 & $\begin{array}{l}-0.231 \\
(0.134)\end{array}$ & -0.0003 & $\begin{array}{l}-0.346 \\
(0.256)\end{array}$ & -0.0002 \\
\hline Higher education & $\begin{array}{l}-0.835^{* * *} \\
(0.101)\end{array}$ & -0.0059 & $\begin{array}{l}-1.554^{* * * *} \\
(0.279)\end{array}$ & -0.0012 & $\begin{array}{l}-0.793 \\
(0.447)\end{array}$ & -0.0004 \\
\hline Wealth & $\begin{array}{l}-0.140^{* * * *} \\
(0.022)\end{array}$ & -0.0012 & $\begin{array}{l}-0.148^{* * * *} \\
(0.041)\end{array}$ & -0.0002 & $\begin{array}{l}-0.131^{*} \\
(0.052)\end{array}$ & -0.0001 \\
\hline Local unemployment rate & $\begin{array}{l}-0.015 \\
(0.014)\end{array}$ & -0.0001 & $\begin{array}{l}0.078^{* *} \\
(0.030)\end{array}$ & 0.0001 & $\begin{array}{l}0.133^{*} \\
(0.057)\end{array}$ & 0.0001 \\
\hline $\begin{array}{l}\text { Primary and secondary } \\
\text { industries }\end{array}$ & $\begin{array}{l}-0.177 * \\
(0.079)\end{array}$ & -0.0015 & $\begin{array}{l}-0.321 * \\
(0.156)\end{array}$ & -0.0004 & $\begin{array}{l}0.237 \\
(0.452)\end{array}$ & 0.0002 \\
\hline $\begin{array}{l}\text { Wholesale, retail, hotels, } \\
\text { restaurants }\end{array}$ & $\begin{array}{l}-0.217^{*} \\
(0.103)\end{array}$ & -0.0018 & $\begin{array}{l}-0.530^{*} \\
(0.218)\end{array}$ & -0.0005 & $\begin{array}{l}0.646 \\
(0.515)\end{array}$ & 0.0006 \\
\hline $\begin{array}{l}\text { Transportation, } \begin{array}{r}\text { postal, } \\
\text { telegraph, financing, } \\
\text { private services }\end{array}\end{array}$ & $\begin{array}{l}0.036 \\
(0.090)\end{array}$ & 0.0003 & $\begin{array}{l}-1.077 * * * \\
(0.245)\end{array}$ & -0.0009 & $\begin{array}{l}0.143 \\
(0.539)\end{array}$ & 0.0001 \\
\hline Non-employed/ missing & $\begin{array}{l}-1.479 * * * \\
(0.180)\end{array}$ & -0.0079 & $\begin{array}{l}-0.825^{* * *} \\
(0.256)\end{array}$ & -0.0007 & $\begin{array}{l}1.936 * * * \\
(0.426)\end{array}$ & 0.0034 \\
\hline Constant & $\begin{array}{l}-5.313^{* * *} \\
(0.202)\end{array}$ & & $\begin{array}{l}-8.181^{* * *} \\
(0.505)\end{array}$ & & $\begin{array}{l}-9.266^{* * *} \\
(0.757)\end{array}$ & \\
\hline Log likelihood & \multicolumn{6}{|c|}{-6724} \\
\hline Number of observations & \multicolumn{6}{|c|}{52066} \\
\hline
\end{tabular}


Table A3. Multinomial logit estimates and marginal effects of determinants of early retirement through different pathways, men, 1995 (standard errors in parentheses).

\begin{tabular}{|c|c|c|c|c|c|c|}
\hline Variable & Employmen & & UIB domina & ed pathways & Other path & ays \\
\hline & Coefficient & Marg. effect & Coefficient & Marg. effect & Coefficient & Marg. effect \\
\hline Aged 50-54 & $\begin{array}{l}1.278 * * * \\
(0.156)\end{array}$ & 0.0114 & $\begin{array}{l}3.214^{* * *} \\
(0.249)\end{array}$ & 0.0456 & $\begin{array}{l}1.315^{* * *} \\
(0.246)\end{array}$ & 0.0017 \\
\hline Aged 55-59 & $\begin{array}{l}1.835 * * * \\
(0.153)\end{array}$ & 0.0215 & $\begin{array}{l}3.772 * * * \\
(0.248)\end{array}$ & 0.0891 & $\begin{array}{l}1.147 * * * \\
(0.268)\end{array}$ & 0.0014 \\
\hline Aged 60-66 & $\begin{array}{l}4.099 * * * \\
(0.141)\end{array}$ & 0.1648 & $\begin{array}{l}3.794 * * * \\
(0.252)\end{array}$ & 0.0962 & $\begin{array}{l}0.938 * * \\
(0.317)\end{array}$ & 0.0008 \\
\hline Immigrant & $\begin{array}{l}-0.086 \\
(0.165)\end{array}$ & -0.0006 & $\begin{array}{l}0.358^{* *} \\
(0.130)\end{array}$ & 0.0022 & $\begin{array}{l}0.850 * * * \\
(0.242)\end{array}$ & 0.0013 \\
\hline Single & $\begin{array}{l}-0.031 \\
(0.073)\end{array}$ & -0.0002 & $\begin{array}{l}0.276^{* * * *} \\
(0.073)\end{array}$ & 0.0016 & $\begin{array}{l}0.876 * * * \\
(0.173)\end{array}$ & 0.0012 \\
\hline Vocational training & $\begin{array}{l}-0.083 \\
(0.061)\end{array}$ & -0.0006 & $\begin{array}{l}-0.174 * * \\
(0.067)\end{array}$ & -0.0009 & $\begin{array}{l}-0.399 * \\
(0.173)\end{array}$ & -0.0004 \\
\hline Higher education & $\begin{array}{l}-0.867 * * * \\
(0.090)\end{array}$ & -0.0048 & $\begin{array}{l}-1.328^{* * * *} \\
(0.123)\end{array}$ & -0.0052 & $\begin{array}{l}-2.184 * * * \\
(0.431)\end{array}$ & -0.0014 \\
\hline Wealth & $\begin{array}{l}-0.047^{* *} \\
(0.016)\end{array}$ & -0.0003 & $\begin{array}{l}-0.047 * * \\
(0.017)\end{array}$ & -0.0002 & $\begin{array}{l}-0.054 * * \\
(0.020)\end{array}$ & -0.0001 \\
\hline Local unemployment rate & $\begin{array}{l}0.353 * * * \\
(0.011)\end{array}$ & 0.0024 & $\begin{array}{l}0.376^{* * * *} \\
(0.012)\end{array}$ & 0.0020 & $\begin{array}{l}0.295 * * * \\
(0.030)\end{array}$ & 0.0003 \\
\hline $\begin{array}{l}\text { Primary and secondary } \\
\text { industries }\end{array}$ & $\begin{array}{l}-0.359 * * * \\
(0.073)\end{array}$ & -0.0024 & $\begin{array}{l}-0.223 * * \\
(0.082)\end{array}$ & -0.0011 & $\begin{array}{l}-0.736 * * \\
(0.258)\end{array}$ & -0.0007 \\
\hline $\begin{array}{l}\text { Wholesale, retail, hotels, } \\
\text { restaurants }\end{array}$ & $\begin{array}{l}-0.458 * * * \\
(0.096)\end{array}$ & -0.0027 & $\begin{array}{l}-0.301 * * \\
(0.107)\end{array}$ & -0.0014 & $\begin{array}{l}-0.320 \\
(0.300)\end{array}$ & -0.0003 \\
\hline $\begin{array}{l}\text { Transportation, postal, } \\
\text { telegraph, financing, } \\
\text { private services }\end{array}$ & $\begin{array}{l}-0.200^{*} \\
(0.082)\end{array}$ & -0.0013 & $\begin{array}{l}-0.844^{* * * *} \\
(0.112)\end{array}$ & -0.0035 & $\begin{array}{l}-0.969 * * \\
(0.328)\end{array}$ & -0.0007 \\
\hline Non-employed/missing & $\begin{array}{l}-2.603^{* * *} \\
(0.204)\end{array}$ & -0.0083 & $\begin{array}{l}-0.687^{* * *} \\
(0.114)\end{array}$ & -0.0028 & $\begin{array}{l}0.607^{* *} \\
(0.222)\end{array}$ & 0.0008 \\
\hline Constant & $\begin{array}{l}-9.210^{* * * *} \\
(0.201)\end{array}$ & & $\begin{array}{l}-10.745^{* * *} \\
(0.294)\end{array}$ & & $\begin{array}{l}-9.780 * * * \\
(0.464)\end{array}$ & \\
\hline Log likelihood & \multicolumn{6}{|c|}{-10181} \\
\hline Number of observations & \multicolumn{6}{|c|}{56902} \\
\hline
\end{tabular}


Table A4. Multinomial logit estimates and marginal effects of determinants of early retirement through different pathways, men, 2000 (standard errors in parentheses).

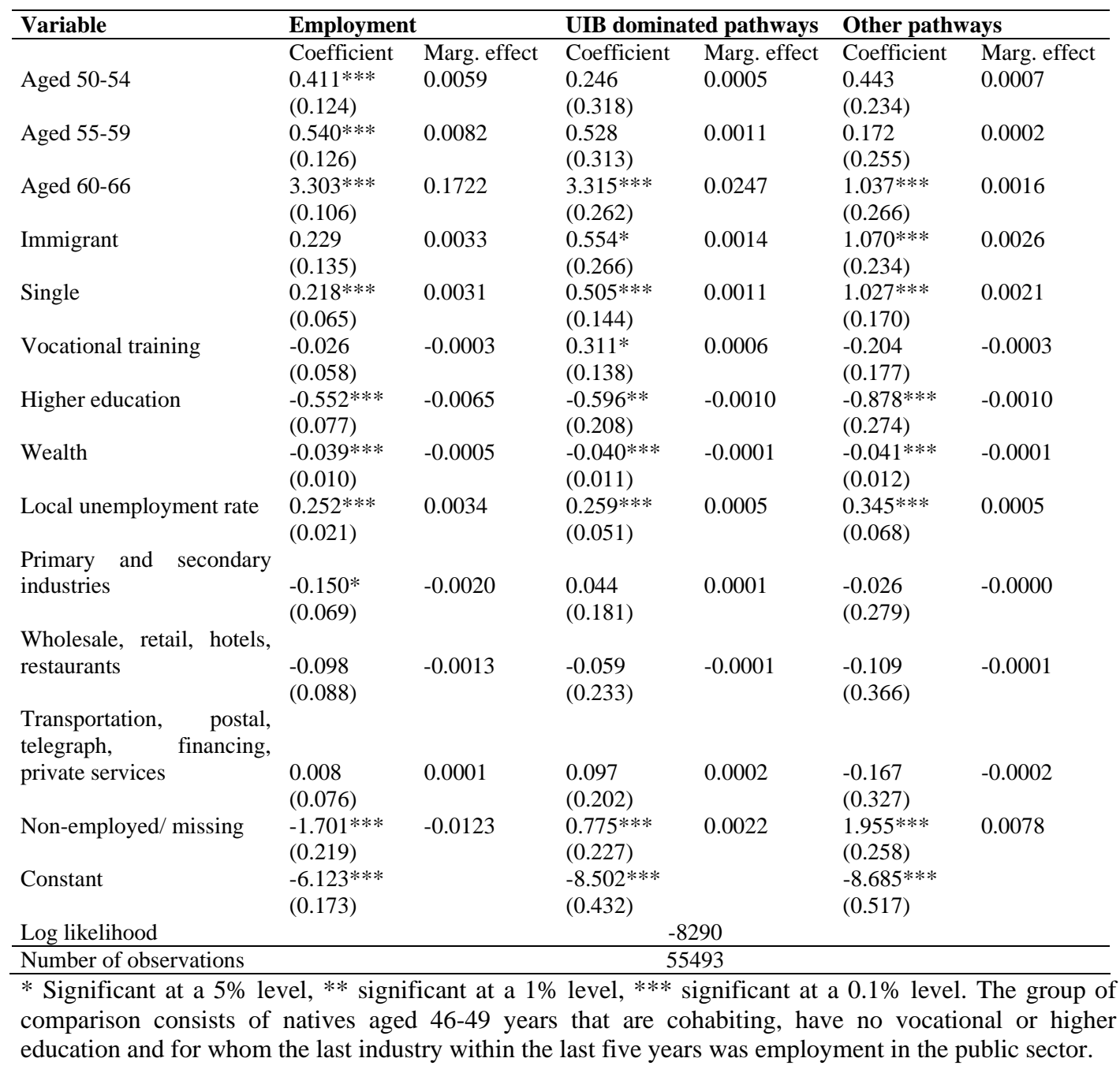


Table A5. Multinomial logit estimates and marginal effects of determinants of early retirement through different pathways, women, 1990 (standard errors in parentheses).

\begin{tabular}{|c|c|c|c|c|c|c|}
\hline Variable & Employmen & & UIB domin & ed pathways & Other pathy & ays \\
\hline & Coefficient & Marg. effect & Coefficient & Marg. effect & Coefficient & Marg. effect \\
\hline Aged 50-54 & $\begin{array}{l}0.907 * * * \\
(0.126)\end{array}$ & 0.0172 & $\begin{array}{l}0.673^{*} \\
(0.335)\end{array}$ & 0.0016 & $\begin{array}{l}-0.178 \\
(0.451)\end{array}$ & -0.0001 \\
\hline Aged 55-59 & $\begin{array}{l}1.484 * * * \\
(0.121)\end{array}$ & 0.0366 & $\begin{array}{l}1.568 * * * \\
(0.303)\end{array}$ & 0.0055 & $\begin{array}{l}0.027 \\
(0.453)\end{array}$ & -0.0000 \\
\hline Aged 60-66 & $\begin{array}{l}3.522^{* * *} \\
(0.108)\end{array}$ & 0.2251 & $\begin{array}{l}4.070 * * * \\
(0.268)\end{array}$ & 0.0510 & $\begin{array}{l}1.794 * * * \\
(0.350)\end{array}$ & 0.0017 \\
\hline Immigrant & $\begin{array}{l}0.235 \\
(0.149)\end{array}$ & 0.0039 & $\begin{array}{l}0.418 \\
(0.293)\end{array}$ & 0.0011 & $\begin{array}{l}0.312 \\
(0.602)\end{array}$ & 0.0002 \\
\hline Single & $\begin{array}{l}0.144^{*} \\
(0.064)\end{array}$ & 0.0023 & $\begin{array}{l}-0.334 * \\
(0.145)\end{array}$ & -0.0007 & $\begin{array}{l}0.864 * * \\
(0.282)\end{array}$ & 0.0007 \\
\hline Vocational training & $\begin{array}{l}-0.382 * * * \\
(0.068)\end{array}$ & -0.0054 & $\begin{array}{l}-0.282^{*} \\
(0.135)\end{array}$ & -0.0006 & $\begin{array}{l}-0.547 \\
(0.338)\end{array}$ & -0.0003 \\
\hline Higher education & $\begin{array}{l}-0.619 * * * \\
(0.092)\end{array}$ & -0.0078 & $\begin{array}{l}-1.466^{* * *} \\
(0.291)\end{array}$ & -0.0021 & $\begin{array}{l}-0.815 \\
(0.543)\end{array}$ & -0.0004 \\
\hline Wealth & $\begin{array}{l}-0.184 * * \\
(0.064)\end{array}$ & -0.0028 & $\begin{array}{l}-0.285^{*} \\
(0.139)\end{array}$ & -0.0006 & $\begin{array}{l}-0.582 * * * \\
(0.172)\end{array}$ & -0.0004 \\
\hline Local unemployment rate & $\begin{array}{l}-0.011 \\
(0.013)\end{array}$ & -0.0002 & $\begin{array}{l}0.052 \\
(0.028)\end{array}$ & 0.0001 & $\begin{array}{l}-0.124 \\
(0.067)\end{array}$ & -0.0001 \\
\hline $\begin{array}{l}\text { Primary and secondary } \\
\text { industries }\end{array}$ & $\begin{array}{l}-0.214^{* *} \\
(0.076)\end{array}$ & -0.0030 & $\begin{array}{l}-0.135 \\
(0.160)\end{array}$ & -0.0003 & $\begin{array}{l}-0.356 \\
(0.570)\end{array}$ & -0.0002 \\
\hline $\begin{array}{l}\text { Wholesale, retail, hotels, } \\
\text { restaurants }\end{array}$ & $\begin{array}{l}-0.309 * * * \\
(0.093)\end{array}$ & -0.0042 & $\begin{array}{l}0.453 * * \\
(0.156)\end{array}$ & 0.0012 & $\begin{array}{l}0.670 \\
(0.446)\end{array}$ & 0.0006 \\
\hline $\begin{array}{l}\begin{array}{l}\text { Transportation, } \\
\text { telegraph, } \\
\text { private services }\end{array}\end{array}$ & $\begin{array}{l}-0.222 * \\
(0.091)\end{array}$ & -0.0031 & $\begin{array}{l}-1.295^{* * *} \\
(0.316)\end{array}$ & -0.0018 & $\begin{array}{l}0.015 \\
(0.568)\end{array}$ & 0.0000 \\
\hline Non-employed/missing & $\begin{array}{l}-1.398^{* * * *} \\
(0.135)\end{array}$ & -0.0137 & $\begin{array}{l}-0.124 \\
(0.178)\end{array}$ & -0.0002 & $\begin{array}{l}1.644 * * * \\
(0.344)\end{array}$ & 0.0022 \\
\hline Constant & $\begin{array}{l}-4.614^{* * *} \\
(0.167)\end{array}$ & & $\begin{array}{l}-7.126 * * * \\
(0.386)\end{array}$ & & $\begin{array}{l}-6.395^{* * *} \\
(0.733)\end{array}$ & \\
\hline Log likelihood & & & & 28 & & \\
\hline Number of observations & & & & 325 & & \\
\hline
\end{tabular}


Table A6. Multinomial logit estimates and marginal effects of determinants of early retirement through different pathways, women, 1995 (standard errors in parentheses).

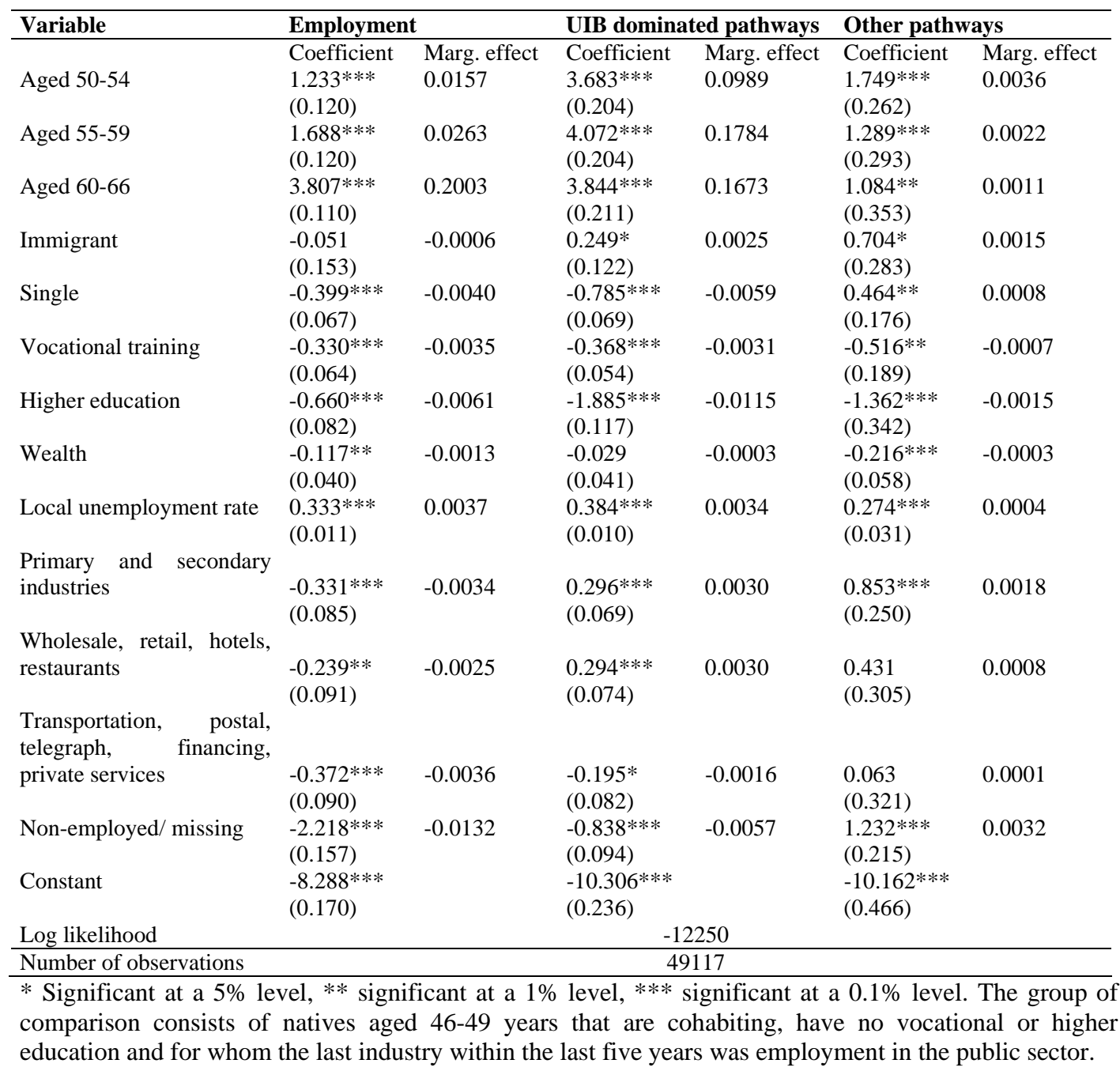


Table A7. Multinomial logit estimates and marginal effects of determinants of early retirement through different pathways, women, 2000 (standard errors in parentheses).

\begin{tabular}{|c|c|c|c|c|c|c|}
\hline Variable & Employmen & & UIB domin & ed pathways & Other path & ays \\
\hline Aged 50-54 & $\begin{array}{l}\text { Coefficient } \\
0.087 \\
(0.119)\end{array}$ & $\begin{array}{l}\text { Marg. effect } \\
0.0012\end{array}$ & $\begin{array}{l}\text { Coefficient } \\
0.679 * \\
(0.313)\end{array}$ & $\begin{array}{l}\text { Marg. effect } \\
0.0017\end{array}$ & $\begin{array}{l}\text { Coefficient } \\
0.897^{* * *} \\
(0.249)\end{array}$ & $\begin{array}{l}\text { Marg. effect } \\
0.0022\end{array}$ \\
\hline Aged 55-59 & $\begin{array}{l}0.455^{* * *} \\
(0.118)\end{array}$ & 0.0071 & $\begin{array}{l}0.849 * * \\
(0.316)\end{array}$ & 0.0024 & $\begin{array}{l}0.354 \\
(0.273)\end{array}$ & 0.0008 \\
\hline Aged 60-66 & $\begin{array}{l}3.501^{* * *} \\
(0.098)\end{array}$ & 0.2220 & $\begin{array}{l}3.811^{* * *} \\
(0.279)\end{array}$ & 0.0466 & $\begin{array}{l}2.237 * * * \\
(0.253)\end{array}$ & 0.0093 \\
\hline Immigrant & $\begin{array}{l}0.242 \\
(0.137)\end{array}$ & 0.0038 & $\begin{array}{l}0.211 \\
(0.285)\end{array}$ & 0.0005 & $\begin{array}{l}0.263 \\
(0.259)\end{array}$ & 0.0006 \\
\hline Single & $\begin{array}{l}0.022 \\
(0.061)\end{array}$ & 0.0003 & $\begin{array}{l}-0.126 \\
(0.143)\end{array}$ & -0.0003 & $\begin{array}{l}0.257 \\
(0.155)\end{array}$ & 0.0006 \\
\hline Vocational training & $\begin{array}{l}-0.231^{* * *} \\
(0.063)\end{array}$ & -0.0032 & $\begin{array}{l}0.083 \\
(0.130)\end{array}$ & 0.0002 & $\begin{array}{l}-0.548^{* * *} \\
(0.163)\end{array}$ & -0.0011 \\
\hline Higher education & $\begin{array}{l}-0.446^{* * *} \\
(0.074)\end{array}$ & -0.0057 & $\begin{array}{l}-1.044^{* * *} \\
(0.226)\end{array}$ & -0.0019 & $\begin{array}{l}-1.248^{* * *} \\
(0.267)\end{array}$ & -0.0021 \\
\hline Wealth & $\begin{array}{l}-0.120^{* * *} \\
(0.024)\end{array}$ & -0.0017 & $\begin{array}{l}-0.153^{* * *} \\
(0.034)\end{array}$ & -0.0003 & $\begin{array}{l}-0.155^{* * *} \\
(0.038)\end{array}$ & -0.0003 \\
\hline Local unemployment rate & $\begin{array}{l}0.232 * * * \\
(0.023)\end{array}$ & 0.0033 & $\begin{array}{l}0.207 * * * \\
(0.050)\end{array}$ & 0.0005 & $\begin{array}{l}0.262 * * * \\
(0.059)\end{array}$ & 0.0005 \\
\hline $\begin{array}{l}\text { Primary and secondary } \\
\text { industries }\end{array}$ & $\begin{array}{l}-0.219 * \\
(0.086)\end{array}$ & -0.0029 & $\begin{array}{l}0.520 * * \\
(0.175)\end{array}$ & 0.0014 & $\begin{array}{l}0.131 \\
(0.277)\end{array}$ & 0.0003 \\
\hline $\begin{array}{l}\text { Wholesale, retail, hotels, } \\
\text { restaurants }\end{array}$ & $\begin{array}{l}0.027 \\
(0.085)\end{array}$ & 0.0004 & $\begin{array}{l}0.187 \\
(0.205)\end{array}$ & 0.0005 & $\begin{array}{l}0.329 \\
(0.276)\end{array}$ & 0.0008 \\
\hline $\begin{array}{l}\text { Transportation, postal, } \\
\text { telegraph, financing, } \\
\text { private services }\end{array}$ & $\begin{array}{l}-0.200 * \\
(0.085)\end{array}$ & -0.0027 & $\begin{array}{l}0.371^{*} \\
(0.182)\end{array}$ & 0.0010 & $\begin{array}{l}0.417 \\
(0.249)\end{array}$ & 0.0010 \\
\hline Non-employed/ missing & $\begin{array}{l}-1.622 * * * \\
(0.186)\end{array}$ & -0.0129 & $\begin{array}{l}0.797 * * * \\
(0.191)\end{array}$ & 0.0026 & $\begin{array}{l}2.175^{* * *} \\
(0.182)\end{array}$ & 0.0138 \\
\hline Constant & $\begin{array}{l}-5.601^{* * *} \\
(0.166)\end{array}$ & & $\begin{array}{l}-7.934^{* * *} \\
(0.412)\end{array}$ & & $\begin{array}{l}-7.959 * * * \\
(0.436)\end{array}$ & \\
\hline Log likelihood & \multicolumn{6}{|c|}{-7768} \\
\hline Number of observations & \multicolumn{6}{|c|}{47836} \\
\hline
\end{tabular}

* Significant at a $5 \%$ level, $* *$ significant at a $1 \%$ level, *** significant at a $0.1 \%$ level. The group of comparison consists of natives aged 46-49 years that are cohabiting, have no vocational or higher education and for whom the last industry within the last five years was employment in the public sector. 
Table A8a. Social security programs

\begin{tabular}{|c|c|c|c|c|}
\hline Name of the program & Rules of eligibility & Replacement rate & $\begin{array}{l}\text { Max. benefit } \\
\text { period }\end{array}$ & Abbreviation \\
\hline $\begin{array}{l}\text { Unemployment } \\
\text { insurance benefits }\end{array}$ & $\begin{array}{l}\text { Voluntary, UI fund } \\
\text { member, former } \\
\text { work, available for } \\
\text { the labour market }\end{array}$ & $\begin{array}{l}90 \% \text { of earnings } \\
\text { subject to a ceiling, } \\
\text { average: } 65 \%\end{array}$ & 4 years & UIB \\
\hline Social welfare benefits & $\begin{array}{l}\text { Unemployment } \\
\text { (without access to } \\
\text { UIB) or social } \\
\text { problems. }\end{array}$ & $\begin{array}{l}60-80 \% \text { of ceiling for } \\
\text { UIB, } \\
\text { means tested }\end{array}$ & Unlimited & SWB \\
\hline Sickness benefits & $\begin{array}{l}\text { Unable to work due } \\
\text { to illness, injury, } \\
\text { childbirth or } \\
\text { adoption; certain } \\
\text { employment record }\end{array}$ & $\begin{array}{l}\text { As UIB, } \\
\text { supplemented by } \\
\text { employer (white } \\
\text { collar) }\end{array}$ & $\begin{array}{l}1 \text { year within } 36 \\
\text { months }\end{array}$ & SB \\
\hline
\end{tabular}

Table A8b. Retirement programs

\begin{tabular}{|c|c|c|c|}
\hline Name of the program & Rules of eligibility & Replacement rate & Abbreviation \\
\hline Old Age Pension & $\begin{array}{l}\text { Age }(67+) \text {, duration of } \\
\text { residence in DK }\end{array}$ & Partly means tested & OAP \\
\hline $\begin{array}{l}\text { Social Disability } \\
\text { Pension }\end{array}$ & $\begin{array}{l}\text { Medical and social criteria, } \\
18-66 \text { years }\end{array}$ & $\begin{array}{l}\text { Three levels, dependent on } \\
\text { working capacity, age }\end{array}$ & SDP \\
\hline $\begin{array}{l}\text { Post Employment } \\
\text { Wage }\end{array}$ & $\begin{array}{l}\text { Member of UI fund } 25 \text { of } \\
30 \text { years, } 60-66 \text { years }\end{array}$ & $\begin{array}{l}90 \% \text { of earnings subject to a } \\
\text { ceiling; high/low wage } \\
\text { earners: } 40 / 70 \%\end{array}$ & PEW \\
\hline $\begin{array}{l}\text { Transitional Benefits } \\
\text { Program ('92-’96) }\end{array}$ & $\begin{array}{l}\text { 55-59 years ( } 50-59) \text {, } \\
\text { unemployed } 12 \text { out of } 15 \\
\text { months }\end{array}$ & $82 \%$ of max. UIB & TBP \\
\hline $\begin{array}{l}\text { Public Employee } \\
\text { Pension }\end{array}$ & 60+ years; public servant & $\begin{array}{l}\text { Actuarially adjusted, } \\
\text { dependent on work history }\end{array}$ & PEP \\
\hline
\end{tabular}

